\title{
Educational Values on Ludruk Story “Tragedi Kebun Tebu" made by Cak Edy Karya
}

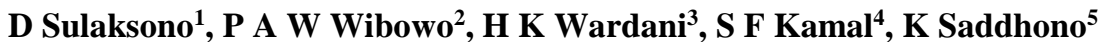 \\ \{1 ${ }^{1}$ ciptaningmintaraga@yahoo.com, ${ }^{2}$ wardani.herlinakusuma@gmail.com, ${ }^{5}$ kundharu.uns@gmail.com $\}$ \\ 1,2,3,4,5 Universitas Sebelas Maret Surakarta, Indonesia
}

\begin{abstract}
Ludruk is one of Javanese traditional play from Eas ra regency. Ludruk contains the local wisdom, because ludruk play te' about 'avanese society in its daily life. This research aims to describe and to olain pout the educational values on Ludruk story Tragedi Kebun Teby y Cak Eu. $J$ arya. This research is descriptive qualitative with sociological lite to approach. Primary data source on this research is Ludruk story Tra di Kes $n$ T ou by Cak Edy Karya. Secondary data source is taken from inf ma s and ascument which are related with the play. The data is collected th gh con nt analysis and in-depth interview with some informants. The resu of this-research shows that Tragedi Kebun Tebu contains some educational va ves. Ed cational values contained in ludruk story are religious values, me al eduo inn social education, and cultural education which reflected from char ter Tragedi Kebun Tebu. These values are reflected in Javanese socie
\end{abstract}

Keywords: Education Valu L L L T, Story, Tragedi Kebun Tebu, Local Wisdom

\section{INTRODUCTION}

A traditional play fom Fast Javu that begins with remo dance is called Ludruk. Ludruk, as a literary work in for of say, contains many positive aspects which are useful for society [1]. Ludruk perform asu " $1 \mathrm{y}$ " $1 \mathrm{ls}$ about the problems of life aspects in society. Before the play begins, the pe torm nce must begin with Remo dance as a welcoming dance to welcome the audiences [2]. f - Lwarus, it is followed by bedhaya, kidungan and proceed to the story that is going to be perfor ed.

Kidungan is a parikan accompanied by gamelan gendhing jula juli. The topics of the kidungan can be a stand alone topic or related to the story that is going to be performed. Kidungan in ludruk play is also being sung by the Remo dancers, bedhayan dancer, and during jokes performances. Jokes is a component that cannot be separated from ludruk play [3]. The costumes for ludruk performers is adjusted based on the story performed. The language used is Javanese used in daily life, not the one used in formal occasion or the one used by the royal family [4]. This is due to the fact that the ludruk performances is first created based on the anxiety felt by the small people.

This article will review about one ludruk play entitled Tragedi Kebun Tebu. This play tells about the trials that befell Sukarsih family. The only child was killed in a sugar cane field. The husband went to jail. In addition, Sukarsih had to face her ambitious and kadonyan (worldly) father. The father acts haphazardly toward his child. Sukarsih was forced to sign the divorce 